University of Nebraska - Lincoln

DigitalCommons@University of Nebraska - Lincoln

\title{
A field study of wind erosion following a grass fire on the Llano Estacado of North America
}

J.E. Stout

USDA-Agricultural Research Service, john.stout@ars.usda.gov

Follow this and additional works at: https://digitalcommons.unl.edu/usdaarsfacpub

Part of the Agricultural Science Commons

Stout, J.E., "A field study of wind erosion following a grass fire on the Llano Estacado of North America" (2012). Publications from USDA-ARS / UNL Faculty. 878.

https://digitalcommons.unl.edu/usdaarsfacpub/878

This Article is brought to you for free and open access by the U.S. Department of Agriculture: Agricultural Research Service, Lincoln, Nebraska at DigitalCommons@University of Nebraska - Lincoln. It has been accepted for inclusion in Publications from USDA-ARS / UNL Faculty by an authorized administrator of DigitalCommons@University of Nebraska - Lincoln. 


\title{
A field study of wind erosion following a grass fire on the Llano Estacado of North America
}

\author{
J.E. Stout* \\ USDA-Agricultural Research Service, 3810 4th Street, Lubbock, TX 79415, USA
}

\section{A R T I C L E I N F O}

\section{Article history:}

Received 30 September 2010

Received in revised form

31 January 2012

Accepted 1 February 2012

Available online 3 March 2012

\section{Keywords:}

Aeolian

Blown sand

Grassland

Saltation

Wildfire

\begin{abstract}
A B S T R A C T
Interactions between earth, wind, and fire have always played an important role in the formation and evolution of the level plains of the Llano Estacado of North America. The uppermost sediments of this vast region are aeolian deposits, formed by aeolian deposition into grassland vegetation. Grass cover enhances aeolian deposition by slowing near-surface winds and vegetation secures sediments once they are deposited. The benefits of grass cover, however, are lost when occasional fires remove protective vegetation from fields. After a fire, the underlying soil surface becomes exposed and susceptible to wind erosion until the vegetative cover is re-established. The purpose of this study was to explore the post-fire recovery process by monitoring temporal variations in aeolian transport and changes in the threshold velocity of a burned grass field located in Lubbock County, Texas. A continuous record of wind erosion activity was obtained during a six-month period as the surface recovered from a highly erodible state to a more vegetated and stable surface. Results suggest that the threshold wind speed of the field increased from less than $10 \mathrm{~m} / \mathrm{s}$ immediately following the fire to above $19 \mathrm{~m} / \mathrm{s}$ in a three-month period as vegetation naturally recovered.
\end{abstract}

Published by Elsevier Ltd.

\section{Introduction}

The Llano Estacado of West Texas and Eastern New Mexico is a vast elevated tableland with a surface area of approximately $80,000 \mathrm{~km}^{2}$ (Reeves and Reeves, 1996). Renowned for its remarkably level surface and the towering escarpments along its outer margins, the elevated plains of the Llano Estacado stand in high relief at the southern end of the Great Plains. The level surface of the Llano Estacado has evolved as a result of episodic deposition of windblown sediments into grassland vegetation over a period of at least one million years, eventually forming an aeolian deposit known as the Blackwater Draw Formation (Gustavson and Holliday, 1999; Holliday, 1990; Holliday, 1991). Grass cover has performed two functions essential to this process: it tends to slow the wind near the surface thereby enhancing aeolian deposition and it stabilizes the surface by preventing deposited sediments from becoming detached and deflated by strong winds.

During the early 20th century, most of the natural grass cover on the Llano Estacado was converted to an extensive patchwork of cropland (Webb, 1931). Not surprisingly, this transformation contributed significantly to the numerous dust storms that

\footnotetext{
* Tel.: +1 808723 5239; fax: +1 8067235272

E-mail address: john.stout@ars.usda.gov.
}

devastated this region during the Dust Bowl years of the 1930's (Laprade, 1957). Improved agricultural practices and federal conservation programs have helped reduce the frequency and intensity of wind erosion events (Stout, 2001; Stout and Lee, 2003). One federal program, called the Conservation Reserve Program (CRP), has provided financial incentives for farmers to return highly erodible cropland to native grass cover for periods of ten to fifteen years. Today, CRP acreage typically accounts for approximately $10 \%$ of the total cropland in a nine-county region surrounding and including Lubbock County (USDA-NASS, 1997).

As more fields have been replanted to grass, the number of grass fires has also increased noticeably. During dry periods, fires occasionally sweep across CRP fields leaving large tracts of land exposed. Although plains vegetation has evolved to survive such fires (Brown, 1979; Shantz and Zon, 1924), it takes time for a surface to fully recover and during the recovery period, significant wind erosion may occur (Sankey et al., 2009a, 2009b, 2010; Smart et al., 2007).

The opportunity to study wind erosion on a burned CRP field presented itself suddenly on 11 March 2002 when a large fire swept across a grass field located west of Lubbock, Texas (Fig. 1). The fire, which took $4 \mathrm{~h}$ to extinguish, scorched 100 ha as flames were driven by strong northwest winds that often exceeded $20 \mathrm{~m} / \mathrm{s}$. Grasses, which had effectively anchored an Olton clay loam soil, were now reduced to ashes so that the soil surface lay bare and 


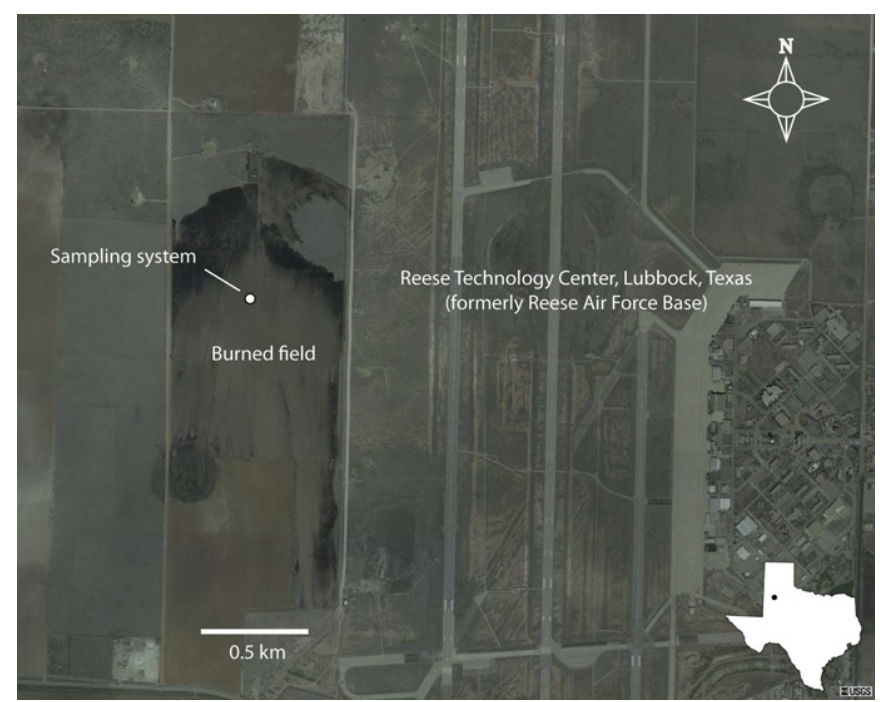

Fig. 1. USGS aerial photograph of the burned grass field taken a few days after the fire. The photo shows the location of the field to the west of the abandoned runways at the former Reese Air Force Base (now called Reese Technology Center), west of Lubbock, Texas. The white dot indicates the location of the sampling system (33.5994 N 102.0572 W).

ready to blow only nine days prior to the spring season - the windiest time of the year on the Llano Estacado. The following report is based upon a six-month investigation of the evolution of this burned field from a condition of maximum erodibility to a fully vegetated stable surface.

\section{Methods}

In preparation for this field study, a wind erosion sampling system (Fig. 2) was designed and constructed. The primary system components included a portable meteorological tower, a piezoelectric saltation sensor (Sensit), and a datalogger. A battery, charged during the day by a solar panel, powered the system.

The sampling system was capable of measuring meteorological variables including rainfall, relative humidity, air temperature, soil temperature, solar radiation, wind speed and direction. Wind speed was measured with a lightweight fast-responding propeller-type

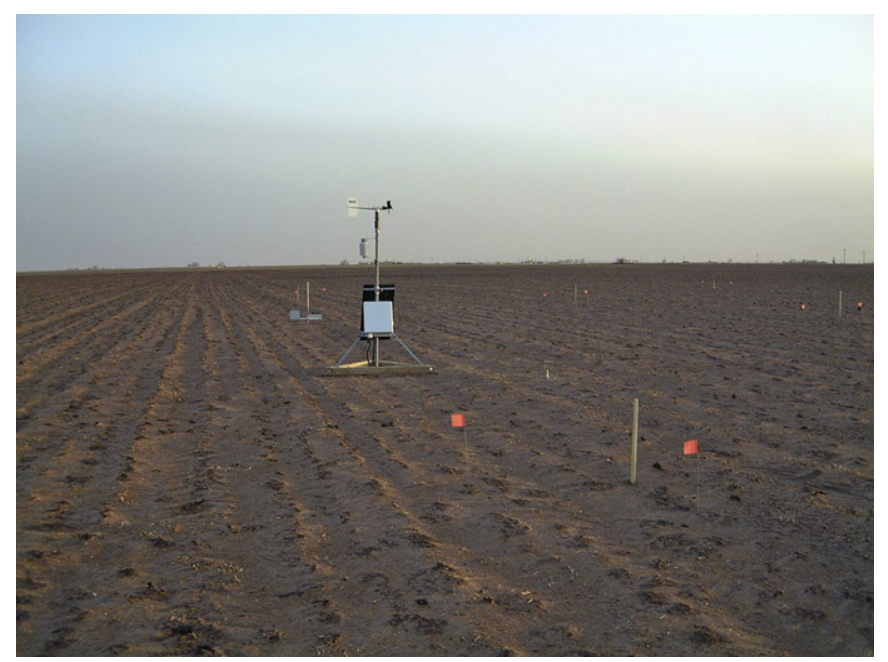

Fig. 2. Sampling system used to measure wind erosion activity and meteorological conditions on the burned field. Photo was taken the day after the fire on 12 March 2002 anemometer mounted at a height of $2 \mathrm{~m}$. Wind speed and direction were sampled at a frequency of $1 \mathrm{~Hz}$ and after each minute, average wind speed, maximum wind speed, standard deviation of wind speed, and resultant wind direction were calculated. Rainfall was measured with a tipping-bucket rain gauge with a resolution of $0.1 \mathrm{~mm}$ per tip and the total rainfall was output each minute. All other meteorological variables were sampled at a frequency of $1 \mathrm{~Hz}$ and summarized each hour. All instruments were tied into a central datalogger mounted on the meteorological tower.

An important goal of this experiment was to obtain a continuous record of wind erosion activity at the site as vegetation slowly recovered. When used properly, the piezoelectric saltation sensor provides a means for acquiring such information. A piezoelectric sensor was placed on the ground at a distance of $10 \mathrm{~m}$ to the west of the meteorological tower. During periods of active saltation, the piezoelectric transducer, set at a height of $5 \mathrm{~cm}$, produced a signal that was used as an on-or-off indicator of wind erosion activity. Each pulse signal generated by each saltating grain that impacted the sensor was detected. If one or more impacts were detected during a given second then that second was registered as one "saltation second." At the end of each minute the total number of saltation seconds was summed.

Although the saltation sensor was designed to primarily respond to the impact of saltating grains (Stockton and Gillette, 1990), it can occasionally provide false indications of blowing sand for various reasons. Precipitation can cause false readings when raindrops or frozen precipitation impact the sensor directly or when rain splashes a mixture of water and sand onto the sensor. Less frequently, false indications occur when animals or insects contact the sensor. In an attempt to limit errors due to false readings, threshold values were not calculated during rain events. Other false readings were detected by sorting the dataset by maximum wind gust and a judgment was made as to whether saltation activity was possible given the maximum-recorded wind speed. Saltation seconds were manually set to zero if the maximum wind gust remained well below threshold. For example, if the maximum wind speed was only $2 \mathrm{~m} / \mathrm{s}$ and threshold is normally around $10 \mathrm{~m} / \mathrm{s}$ one can be fairly certain that wind forces were not sufficient to detach sand grains and that any indications of saltation activity under such low wind conditions are highly suspect. Unfortunately, it was not always possible to distinguish between false readings and real blowing events when maximum wind speed was near threshold and, therefore, the final dataset may still contain a few false indications of blowing sand. These occasional false saltation seconds represent a small fraction of the saltation seconds recorded during the six-month sampling period.

The plan was to set up the sampling system on the first grass field that burned in the Lubbock area. This introduced a certain degree of randomness to the selection of the sampling site since the location was not known until a fire occurred. On 11 March 2002, a few weeks after the completion of the sampling system, a wildfire swept across a grass field located in western Lubbock County (33.5994 N $102.0572 \mathrm{~W}$ ). The sampling system was deployed the following day on 12 March 2002. During the installation period, smoke was still issuing from a few smoldering clumps of grass and the blackened soil surface felt warm to the touch. In most cases, roots of the burned vegetation remained intact, and firmly held the soil. Between the residual grass clumps, however, all that remained were weakly crusted bare surfaces containing limited amounts of fine sand, sand-sized clay aggregates, and burned plant remains.

Although the sampling system was deployed as quickly as possible the day after the fire, wind erosion was observed to have occurred before the sampling system was fully operational. For example, blowing soil was observed by firefighters while the field was actively burning on 11 March as strong northerly winds drove 
the fire to the south. Later that evening, wind speeds were generally light and it is assumed that little or no wind erosion occurred until the following afternoon. Periods of light and intermittent wind erosion were observed while the sampling system was being installed during the afternoon of 12 March. Thus, despite our efforts to deploy quickly, these initial periods of wind erosion activity were not recorded. Once the system was fully operational, a continuous record was obtained over a six-month period starting at 19:00 on 12 March and extending through 4 September 2002.

Another key component of this experiment was the monitoring of vegetation as the surface naturally recovered. Information regarding vegetative cover was obtained in the form of photographic records as well as by cutting, drying and weighing aboveground biomass at selected plots. More specific details of the methodology and results of the vegetation measurements will follow.

\section{Results and discussion}

From March to September, the burned field transformed gradually from a blackened surface devoid of vegetation to a surface with sufficient cover to withstand all but the most extreme wind events. The transformation is clearly visible in the "before-and-after" photographic comparison shown in Fig. 3. These photos demonstrate that, given sufficient time, the surface of the earth, scarred by fire, heals itself. What these photos do not fully convey is the intricate process whereby plants and their seed interact with the physical environment to gradually reclaim stability. This temporal process is more clearly visualized by a series of photographs taken at the twelve selected plots. Sample photographs are shown for three of the twelve plots in Fig. 4.

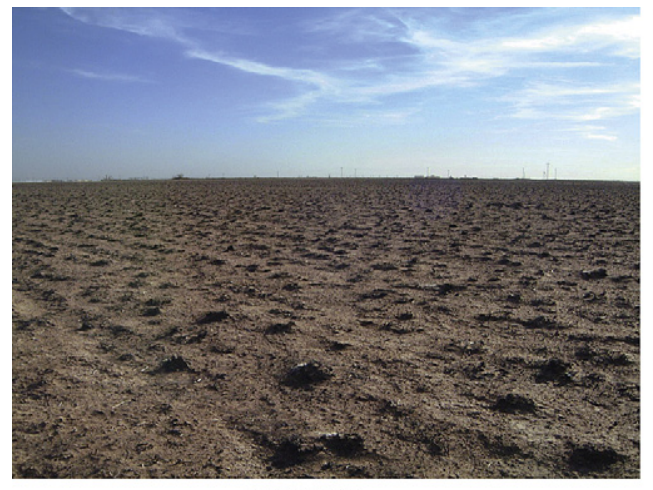

March 12th

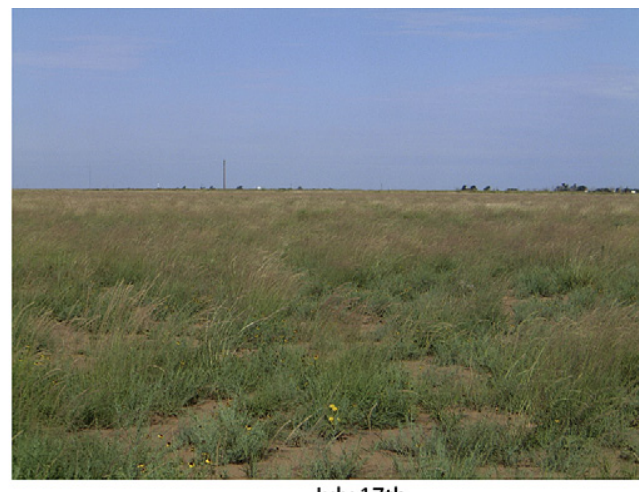

July 17 th

Fig. 3. A photographic comparison showing a blackened surface the day after the fire (12 March 2002$)$ and a fairly well protected surface four months later (17 July 2002 ).

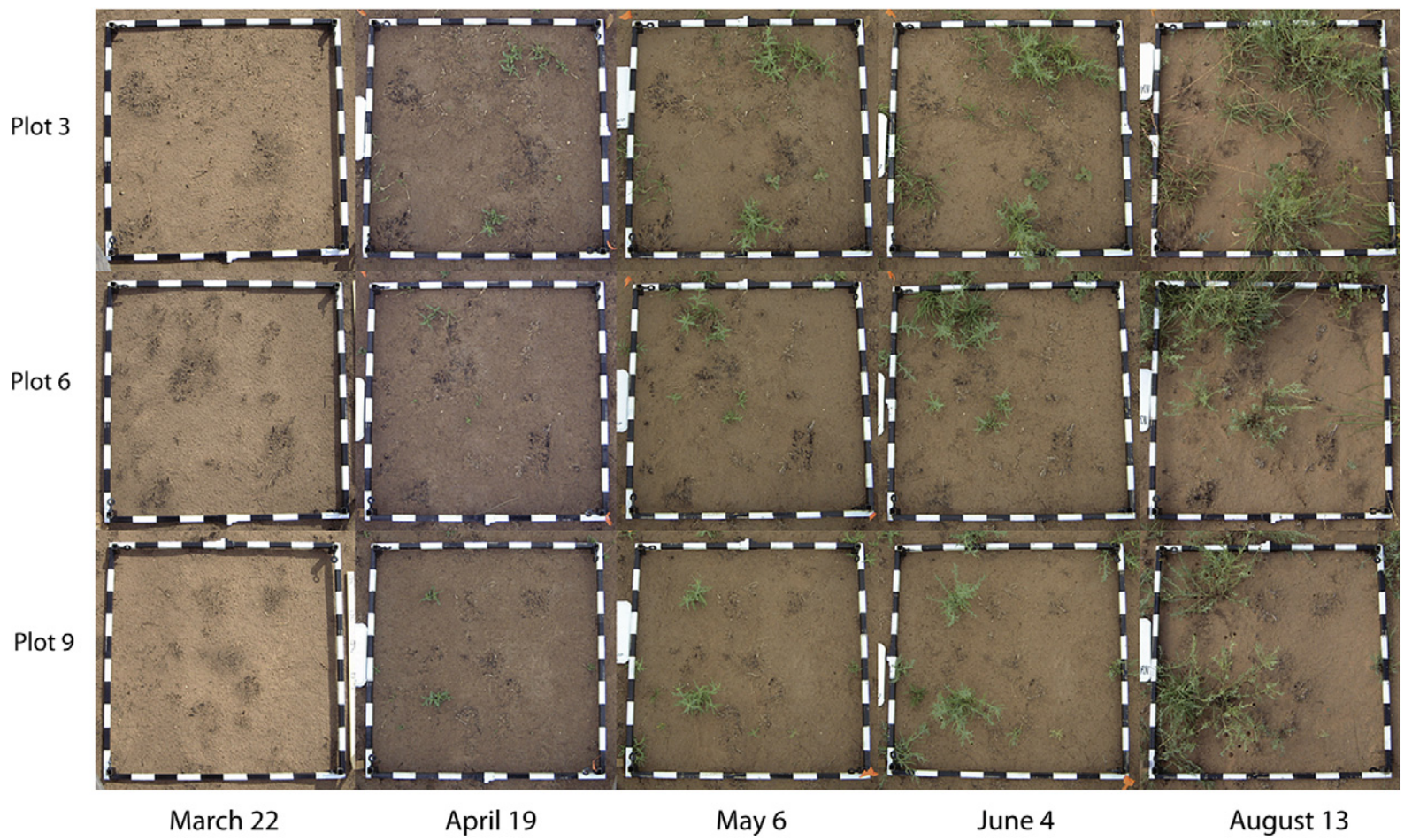

Fig. 4. Series of photographs for three of the twelve plots. The photos show an initial slow recovery followed by a more rapid growth of native weeds and grasses. 
Table 1

Monthly summary of saltation activity and meteorological conditions.

\begin{tabular}{llllllll}
\hline Month & $\begin{array}{l}\text { Avg. } \\
\text { wind } \\
\text { speed } \\
(\mathrm{m} / \mathrm{s})\end{array}$ & $\begin{array}{l}\text { Max. } \\
\text { wind } \\
\text { gust } \\
(\mathrm{m} / \mathrm{s})\end{array}$ & $\begin{array}{l}\text { Total } \\
\text { rain } \\
(\mathrm{mm})\end{array}$ & $\begin{array}{l}\text { Avg. } \\
\mathrm{RH} \\
(\%)\end{array}$ & $\begin{array}{l}\text { Soil } \\
\text { temperature } \\
10 \mathrm{~cm} \text { depth } \\
\left({ }^{\circ} \mathrm{C}\right)\end{array}$ & $\begin{array}{l}\text { Total } \\
\text { saltation } \\
\text { seconds } \\
(\mathrm{s})\end{array}$ & $\begin{array}{l}\text { Monthly } \\
\text { saltation } \\
\text { activity } \\
(-)\end{array}$ \\
\hline March & 5.2 & 19.2 & 77 & 58 & 10.7 & 44,499 & 0.02641 \\
April & 4.9 & 19.0 & 23 & 62 & 17.8 & 26,585 & 0.01026 \\
May & 4.8 & 20.7 & 1 & 51 & 23.6 & 2056 & 0.00077 \\
June & 4.1 & 30.2 & 116 & 58 & 27.2 & 122 & 0.00005 \\
July & 2.7 & 15.6 & 17 & 62 & 28.6 & 0 & 0 \\
August & 3.1 & 18.6 & 48 & 56 & 30.1 & 0 & 0 \\
\hline
\end{tabular}

It should be noted that the field was not plowed, replanted, nor was the field irrigated during the recovery period. It was allowed to recover naturally. Most plants native to the Llano Estacado are well adapted to recover following a fire given adequate moisture and sufficient soil temperatures but due to the late-winter ignition, conditions were not initially favorable for plants to recover.

Although a mixture of rain and snow had fallen nearly five weeks prior to the fire, there was no significant precipitation thereafter, leaving a dry thatch of dormant grasses that was easily ignited. Following the fire, the soil remained dry and highly erodible for another week. The first significant rain event occurred one week after the fire when from 18 to 20 March a total of $23.4 \mathrm{~mm}$ of rain fell. Thereafter, there was generally adequate moisture for seed germination and plant growth. During the 175 day observation period, there were 32 days with measurable precipitation for a total of $281 \mathrm{~mm}$ of rain. As shown in Table 1, the months of March and June were the wettest months, accounting for a total of $77 \mathrm{~mm}$ and $116 \mathrm{~mm}$, respectively.

Soil temperature measurements suggest that, after the immediate effects of the fire had dissipated, the temperature of the soil returned to values more typical of late winter on the Llano Estacado (Fig. 5). Soil temperatures, measured at a depth of $10 \mathrm{~cm}$, averaged around $10{ }^{\circ} \mathrm{C}$ during the month of March, with minimum values occasionally dropping below $5{ }^{\circ} \mathrm{C}$. Such cool soil temperatures are suboptimal for seed germination or regrowth of warm-season grasses (Cole et al., 1974). As a result, the first plants to respond were cool-season annual broadleaf weeds, the most dominant
Table 2

Measurements of groundcover obtained from photographs.

\begin{tabular}{lcc}
\hline Date & Days after fire & Groundcover $(\%)$ \\
\hline $3 / 12 / 02$ & 1 & 0 \\
$3 / 22 / 02$ & 10 & 0 \\
$4 / 19 / 02$ & 37 & 1.3 \\
$5 / 3 / 02$ & 51 & 4.3 \\
$6 / 4 / 02$ & 82 & 11.3 \\
$8 / 13 / 02$ & 151 & 29.7 \\
\hline
\end{tabular}

being Texas blueweed (Helianthus ciliaris). The emergence of Texas blueweed is clearly evident in the series of photographs shown in Fig. 4. Often labeled a "noxious weed," Texas blueweed is actually a native perennial plant on the Llano Estacado and appears to play a vital role in post-fire recovery. It grew rapidly, helping to partially stabilize the surface until the slower responding warm-season grasses had a chance to establish.

It was not until mid-April that soil temperatures warmed to above $20^{\circ} \mathrm{C}$ and it was not until May, that soil temperatures consistently remained above $20^{\circ} \mathrm{C}$ throughout the day. These warmer soil temperatures triggered the growth of warm-season grasses, the most abundant species being Sideoats grama (Bouteloua curtipendula), a native grass that has evolved to survive fire. Sideoats grama tends to grow in bunches so that it rarely spreads out sufficiently to cover the surface entirely.

Throughout the six-month sampling period, vegetative cover was periodically photographed at twelve plots located within a $50 \mathrm{~m}$ radius of the sampling system. Plots were initially randomly selected and marked with flags so that it was possible to return to each of the twelve plots to obtain a sequence of photographs of the recovering vegetation. To avoid shadows, photographs were taken only when skies were overcast and sunlight diffused. The results of the groundcover measurements are summarized in Table 2.

In addition to the photographic records, aboveground biomass was measured periodically by cutting, drying, and weighing plants. Six points were randomly selected within a $50 \mathrm{~m}$ radius of the sampling system. A $1 \mathrm{~m}$ by $1 \mathrm{~m}$ square frame was placed over each randomly selected point. Aboveground vegetation was removed from within the frame and stuffed into a paper sack. Contents of each sack were oven dried at a temperature of $75^{\circ} \mathrm{C}$ for $48 \mathrm{~h}$. The

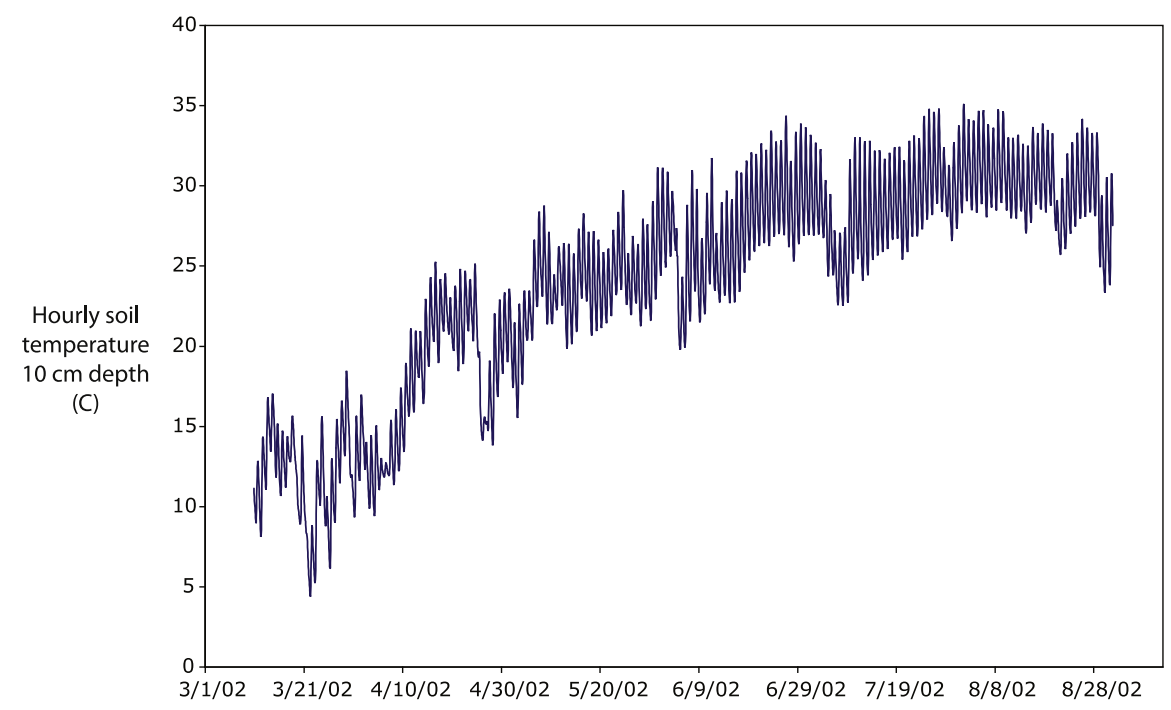

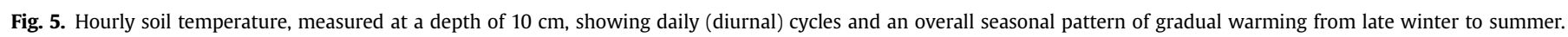


Table 3

Measurements of aboveground biomass.

\begin{tabular}{lcc}
\hline Date & Days after fire & Aboveground biomass $\left(\mathrm{g} / \mathrm{m}^{2}\right)$ \\
\hline $3 / 12 / 02$ & 1 & 0 \\
$4 / 5 / 02$ & 23 & 0.6 \\
$5 / 9 / 02$ & 57 & 12.0 \\
$5 / 30 / 02$ & 78 & 30.0 \\
$6 / 11 / 02$ & 89 & 49.9 \\
$7 / 8 / 02$ & 116 & 102.9 \\
$7 / 30 / 02$ & 138 & 134.4 \\
$8 / 13 / 02$ & 151 & 173.7 \\
\hline
\end{tabular}

mass of the dry vegetation was measured and aboveground biomass was calculated for each plot by dividing the dry mass by the one square meter area of the plot so that the results were expressed as mass per unit area. The overall vegetative cover for the field was estimated by averaging the values taken from all six points.

The results of the biomass measurements, summarized in Table 3, suggest that for the first twenty-three days after the fire, there was only a slight change in aboveground biomass. Photographs also confirm the limited change of vegetative cover during this period (Fig. 4). Vegetative growth began to accelerate in May as soil moisture and soil temperature conditions improved. Substantial growth continued in June and July, slowing somewhat in August as most plants reached maturity.

\subsection{Saltation activity}

Values of hourly saltation activity were calculated by dividing the total number of saltation seconds recorded each hour by $3600 \mathrm{~s}$. The resulting dimensionless hourly saltation activity values are plotted as a time series in Fig. 6 . Note that saltation activity varies from zero to one, where zero indicates no soil movement and unity indicates continuous soil movement.

It is assumed that the field was completely stable before the fire. Thus, prior to the fire, it can be safely assumed that saltation activity would have been negligible. Immediately after the fire, marked by a vertical dashed line in Fig. 6, frequent blowing events appear as intermittent periods of elevated saltation activity. During a few blowing events in March and early April, saltation activity was well above 0.5 , indicating hourly periods with sediment blowing for more than $50 \%$ of the time. After the 2 nd of April, or twenty days after the fire, both the magnitude and frequency of blowing events dropped appreciably and after the 1st of May ( 49 days after the fire) there are no hourly saltation activity values greater than 0.1 .

A monthly summary of the total number of saltation seconds recorded for each month is presented in Table 1 . The results show that a total of 44,499 saltation seconds were recorded in March. A somewhat smaller total of 26,585 saltation seconds were recorded in April. Saltation activity dropped considerably in May and June with totals of 2056 and 122 saltation seconds, respectively. No saltation seconds were recorded in July or August.

The observed reduction in saltation activity primarily reflects changes in vegetative cover as those plants that survived the fire began to recover and seed that remained viable began to germinate. If aboveground biomass is plotted as a function of time (Fig. 7), it shows that vegetation was still at a very low level of less than $10 \mathrm{~g} / \mathrm{m}^{2}$ by 1 May, after which no significant wind erosion events occurred. This suggests that very little vegetation is required to bring about stability.

Although vegetation is an important factor, it is not possible to rule out other factors that may have contributed to a reduction of saltation activity. Wind speed, for example, was observed to decrease in late June, July and August, as shown in Fig. 8 and Table 1. This pattern follows a well-established seasonal trend on the Llano Estacado where the strong winds of spring are often followed by the relative calm of summer.

A closer look at wind speed, however, reveals that mean wind speeds were fairly constant throughout the months of March, April and May. A significant wind speed reduction did not occur until June and July, yet there were substantial reductions in the frequency and intensity of blowing sand from March through May. Clearly, the modest reduction of wind speed cannot account for the substantial reductions in blowing sand during the first three months of the sampling period.

Variations in wind erosion activity may also reflect changes in other environmental factors including rainfall and humidity.

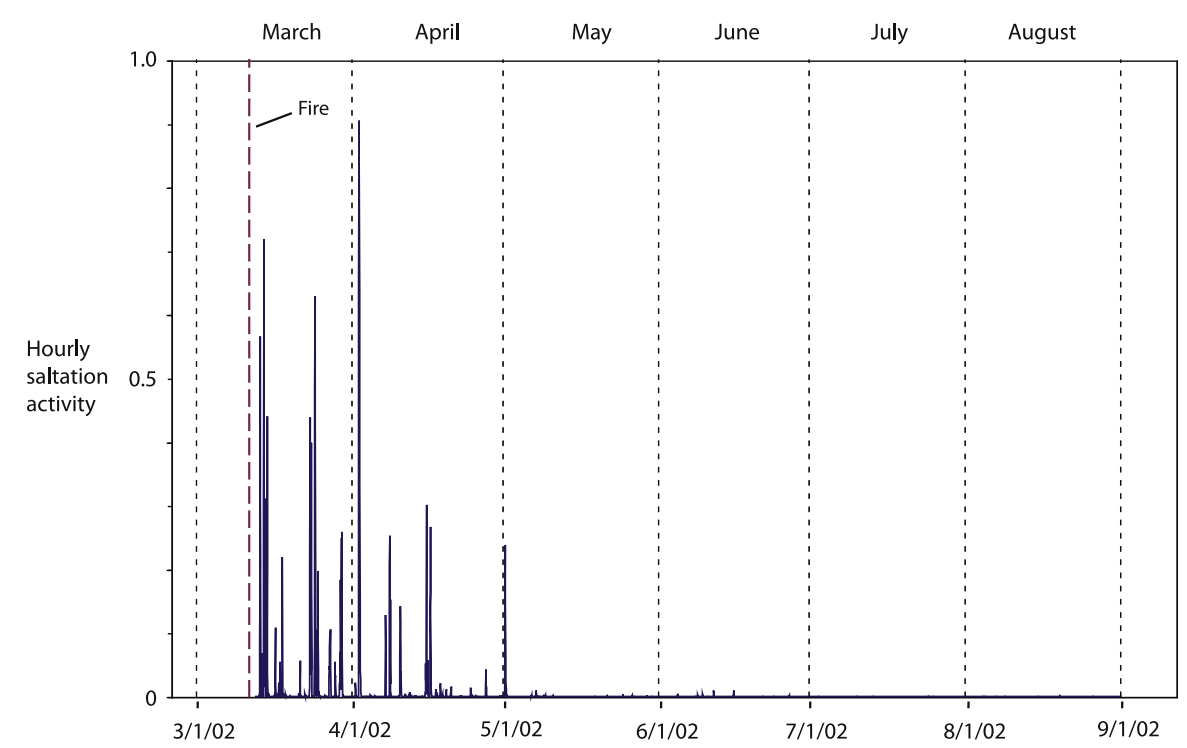

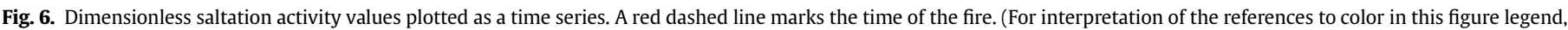
the reader is referred to the web version of this article.) 


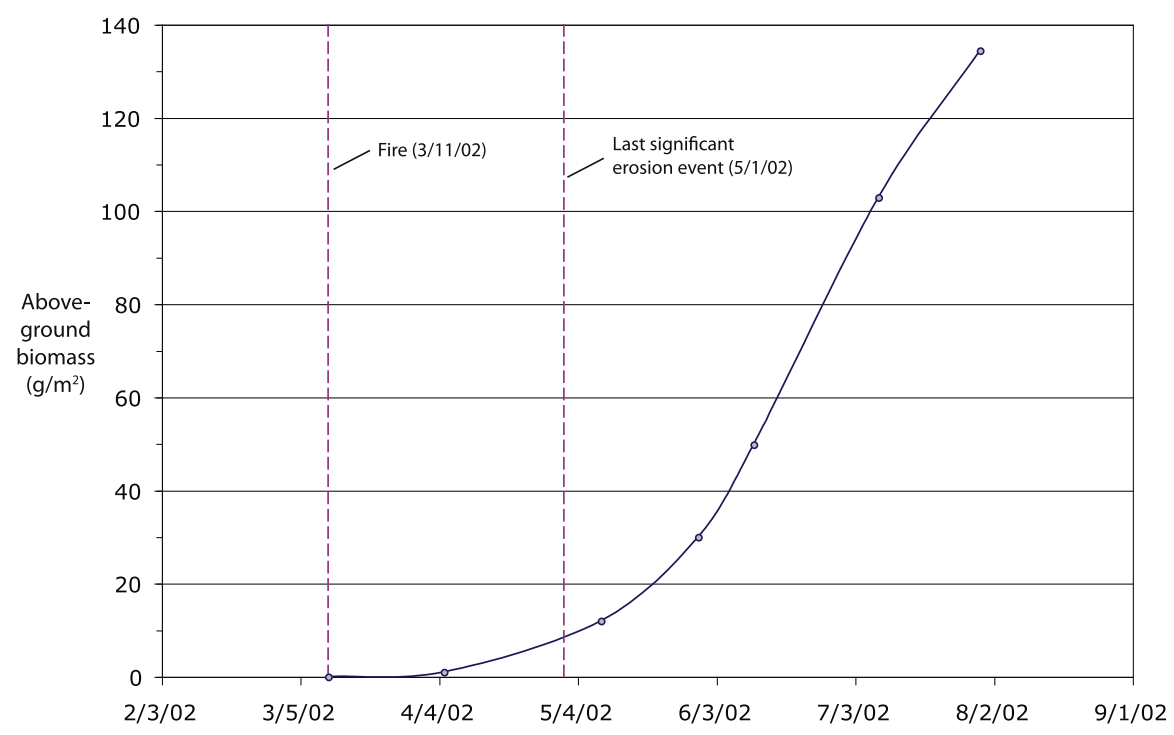

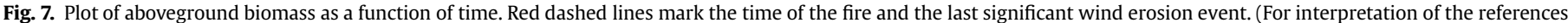
to color in this figure legend, the reader is referred to the web version of this article.)

No clear pattern, however, was observed for these variables. For example, the second largest monthly rainfall of $77 \mathrm{~mm}$ was observed in March during the period of most intense wind erosion activity (Table 1 ). At the opposite extreme, only a trace of rainfall fell in May $(1 \mathrm{~mm})$, yet despite the dry conditions, wind erosion activity was significantly lower than the two previous months.

Another factor that may have influenced saltation activity includes variations in sediment supply. No measurements of the amount of loose material were obtained but occasional observations suggested that the amount of erodible material could vary somewhat from one blowing event to the next. However, the supply of erodible sediment was adequate during the full sixmonth sampling period and although there may have been random changes of sediment supply, there was no systematic depletion of surface sediments during the course of the field study.

\subsection{Threshold wind speed}

One sensitive measure of the susceptibility of a surface to wind erosion is threshold wind speed - the wind speed at which sediment transport is initiated. Low threshold values indicate a surface that is easily eroded by wind whereas higher threshold values indicate a more stable surface. Here an attempt was made to measure changes in the threshold wind speed as vegetation gradually recovered. Threshold values were calculated using the principle of "time fraction equivalence" as first proposed in Stout and Zobeck (1996) and later refined by Stout (2004). The guiding principle of this method is that the fraction of time that saltation activity is detected should be equivalent to the fraction of time that winds exceed threshold: one simply has to determine the value of threshold that yields this time fraction equivalence.

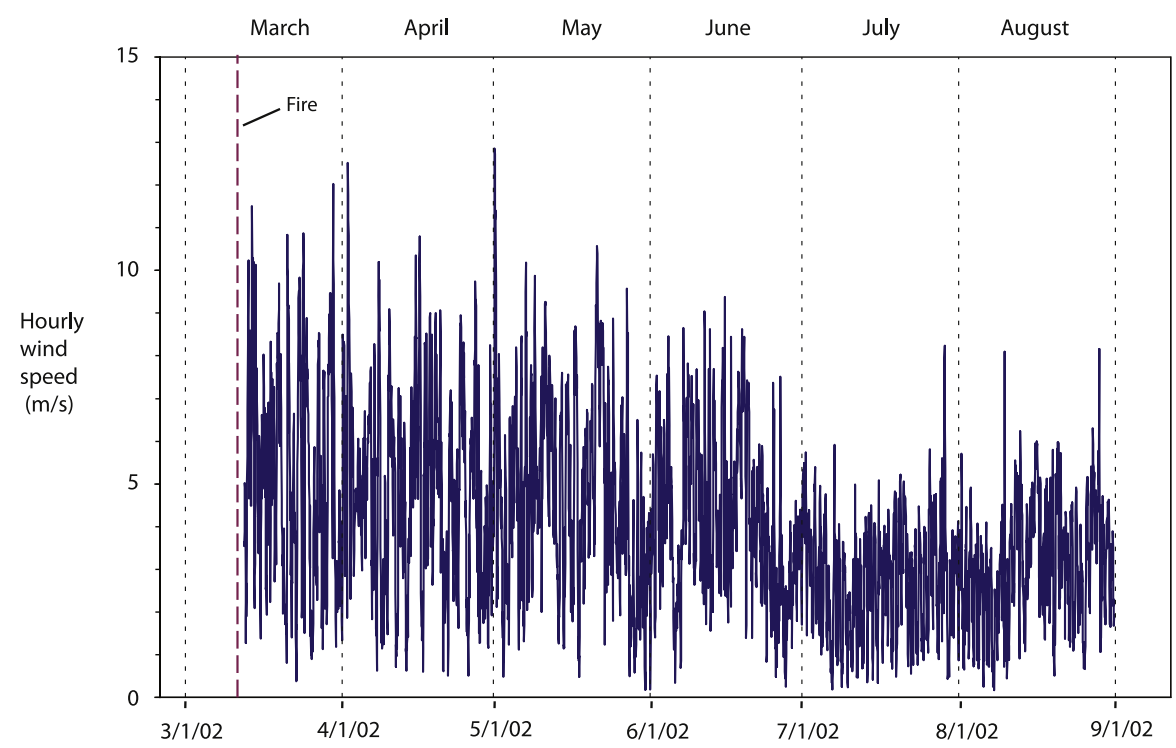

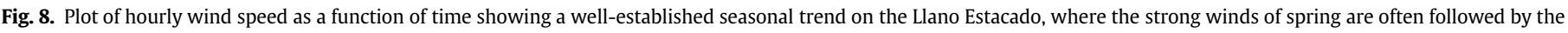
relative stillness of summer. 
Through a simple mathematical calculation, one can determine threshold wind velocity $\left(u_{\mathrm{t}}\right)$ from measurements of mean wind speed $(\bar{u})$, standard deviation of wind speed $(\sigma)$, and saltation $\operatorname{activity}(\gamma)$ :

$u_{\mathrm{t}}=\bar{u}-\sigma \Phi^{-1}(\gamma)$

where $\Phi^{-1}$ represents the inverse of the normal distribution function with saltation activity as the independent variable (Stout, 2004). Here, saltation activity is defined as the fraction of time during each $1 \mathrm{~min}$ period that the piezoelectric saltation sensor detected saltating particles. Prior studies have shown that calculated values of threshold are most reliable when there is significant saltation activity; therefore, calculations of threshold were limited to those $1 \mathrm{~min}$ periods with at least five saltation seconds.

Example calculations are shown for two strong wind events that occurred on 24 March and 1 May (Fig. 9). These examples show threshold values and maximum wind speed plotted from 0600 to 2100 LST. In both cases, wind speed follows a typical diurnal pattern with low wind speeds in the morning, increasing to above threshold during the day, and then decreasing in the evening (Stout, 2010). Once soil movement is initiated, it is possible to calculate threshold values for each minute that soil movement is detected. Although there is some scatter, threshold values remain fairly constant despite the fact that turbulent wind gusts cause wind speed to rise and fall rapidly during the day. A comparison of the threshold values calculated for these two days shows a clear separation with an average threshold of $10.1 \mathrm{~m} / \mathrm{s}$ for 24 March and an appreciably higher average threshold of $14.5 \mathrm{~m} / \mathrm{s}$ for 1 May (Fig. 10).

Similar calculations of threshold were obtained on numerous other days during the six-month sampling period. For each day that soil movement was detected, all of the 1 min threshold values for a given day were averaged to provide daily values (Fig. 11). The results show that there was a general increase of threshold wind speed with time, indicating a surface that moved toward stability as vegetation recovered.
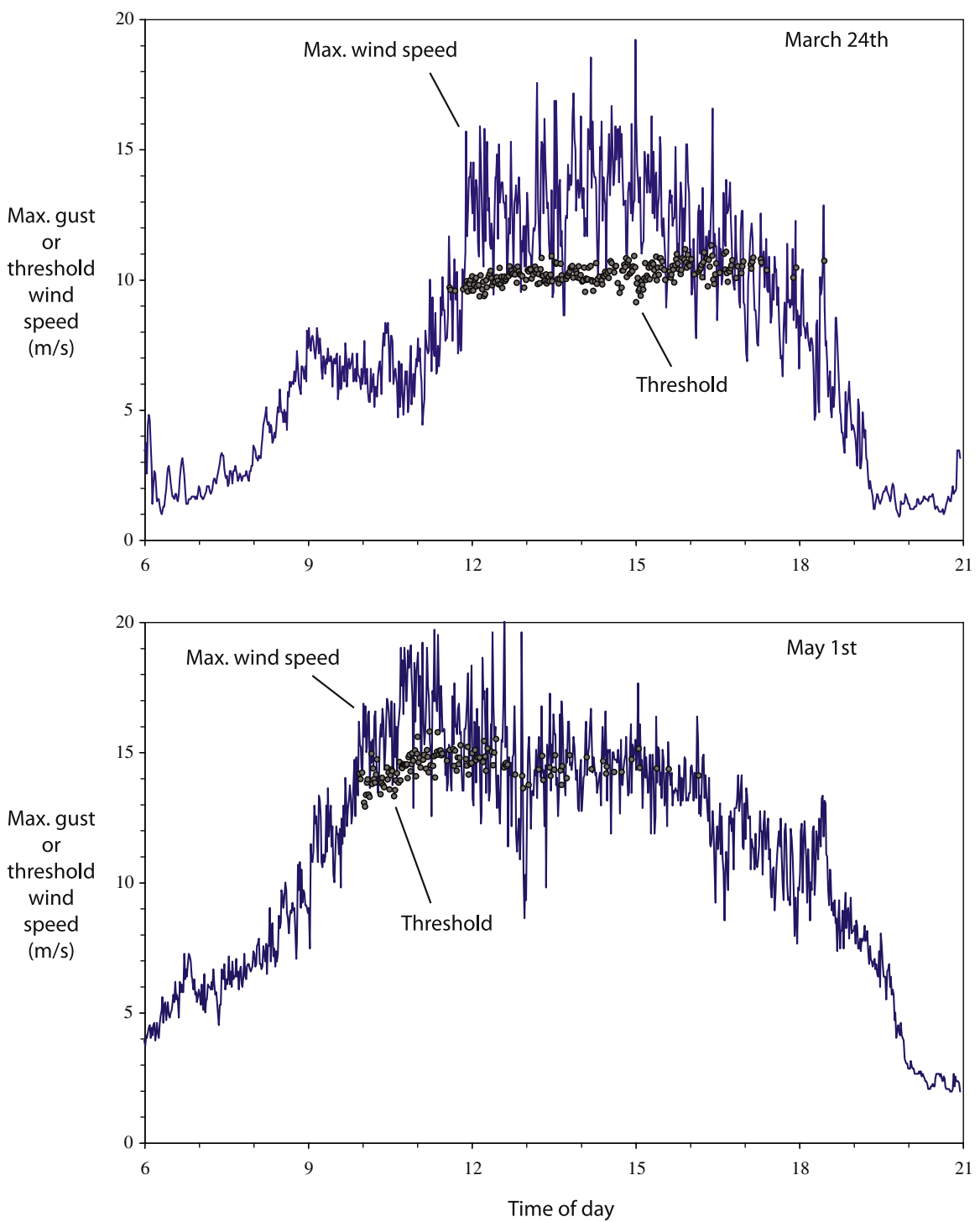

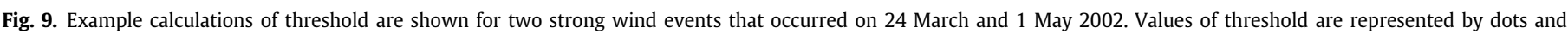
maximum wind speed is plotted as a time series. 


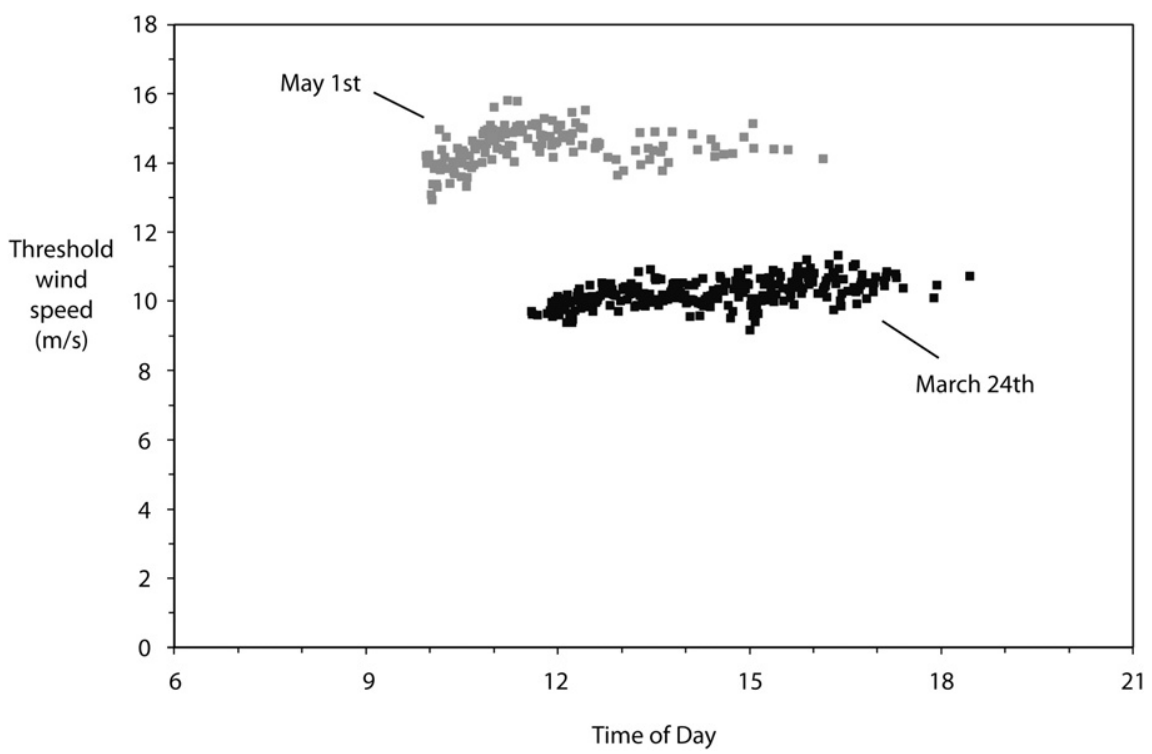

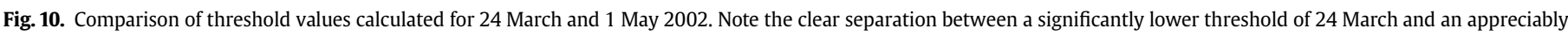
higher threshold of 1 May 2002.

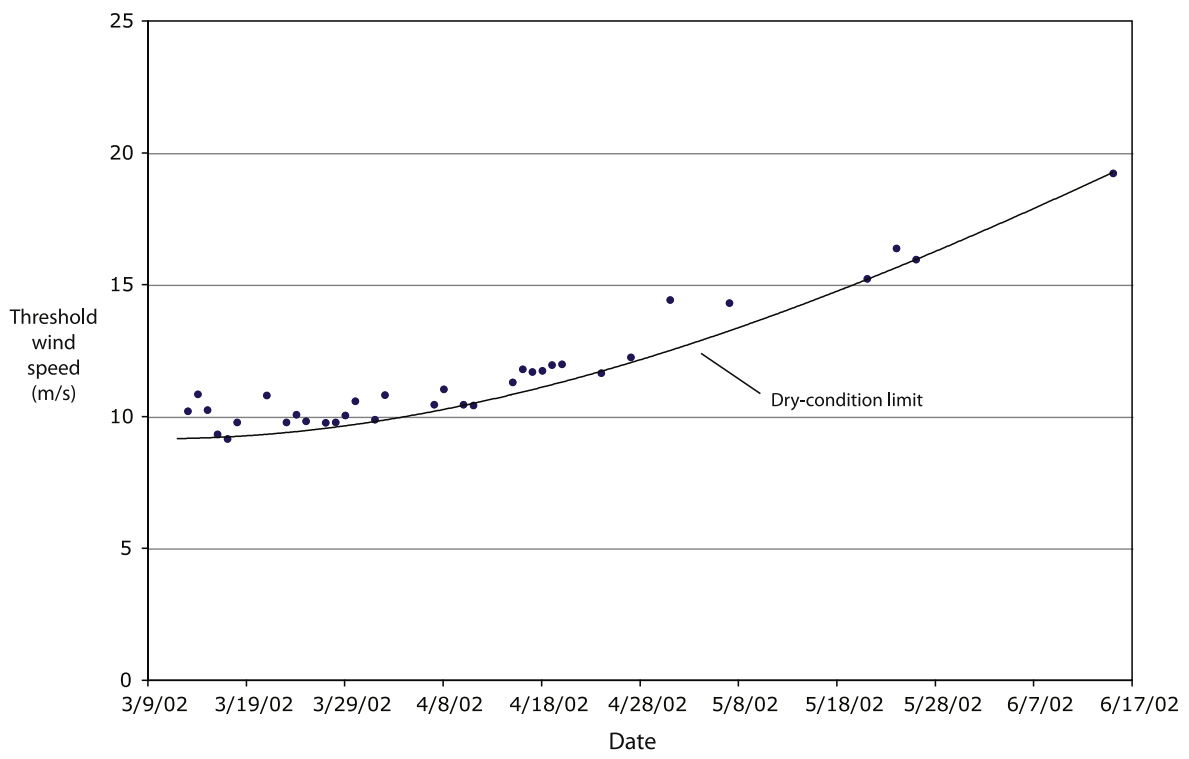

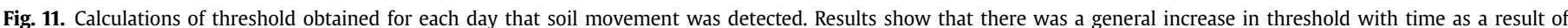

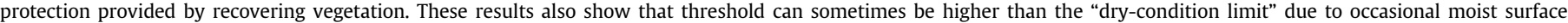
conditions.

It is important to note that threshold for any given day could be temporarily above normal for a number of reasons. For example, a moist surface resulting from prior rainfall could produce an abnormally large value of threshold; however, as a surface dries, a minimum threshold is achieved. Thus, one can define a "drycondition limit" that is the lowest possible threshold for a given day and it is the temporal variation of this dry-condition threshold that is of primary interest.

Overall, results suggest that threshold changed very little during the month of March. More substantial increases occurred in April and May when threshold increased from around $10 \mathrm{~m} / \mathrm{s}$ in early April to closer to $15 \mathrm{~m} / \mathrm{s}$ in late May. The highest dry-condition threshold of $19.2 \mathrm{~m} / \mathrm{s}$ was recorded on 15 June or 93 days after the fire during a brief wind event that gusted above $25 \mathrm{~m} / \mathrm{s}$.

Although it seems natural to plot threshold wind speed as a function of time, changes in threshold were not caused by the mere passage of time. Actually, it was the growth of vegetation that produced an increase in threshold wind speed. Thus, changes of threshold wind speed may be plotted as a direct function of the variable "dry aboveground biomass" rather than the variable "time" (Fig. 12). Note that since biomass and threshold were often not measured the same day, it was necessary to extrapolate between measured values of biomass to obtain values for those days when it was possible to measure threshold. Here, again, an attempt was 


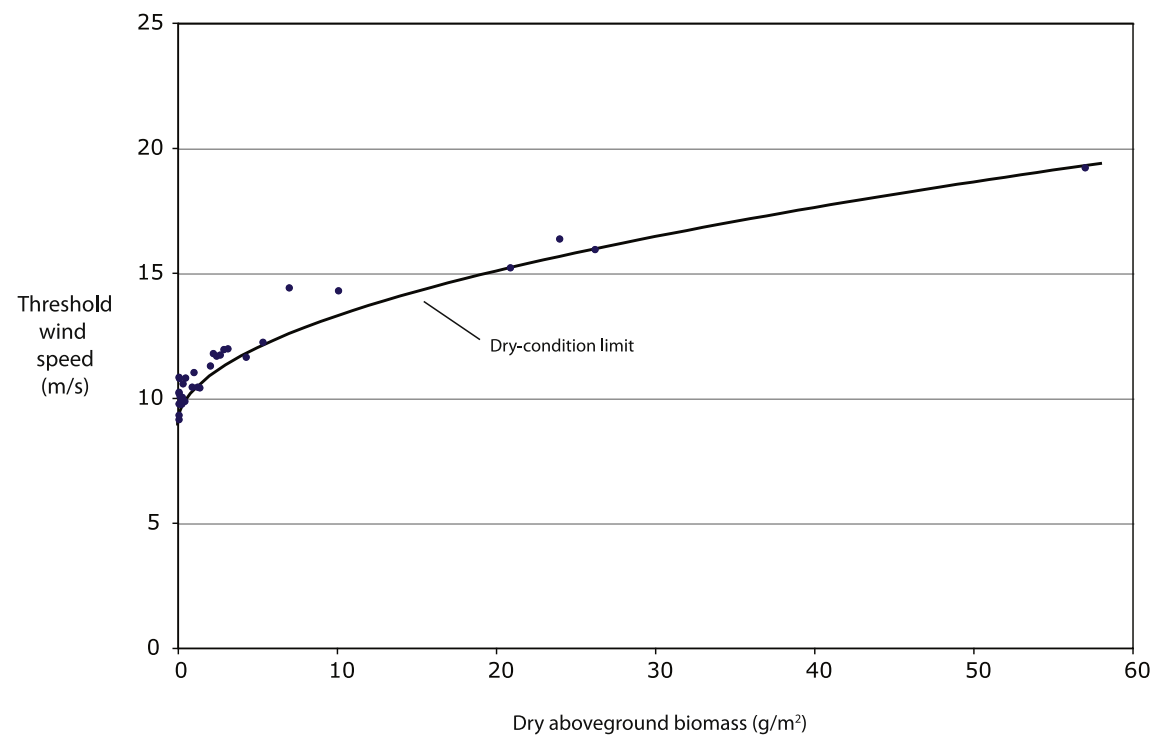

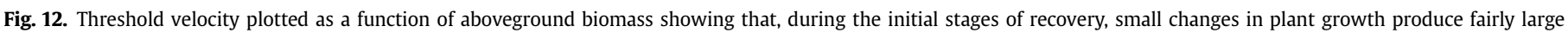
changes in threshold.

made to draw a lower envelope that represents a dry-condition limit. The shape of this curve suggests that during the initial stages of recovery, small changes in plant growth produced fairly large changes in threshold and that at later stages, more substantial changes in vegetation were required to produce a proportional change in threshold wind speed.

\section{Conclusions}

The complex relationships between earth, wind, and fire continue to influence the stability of the surface of the Llano Estacado. In a region where the uppermost sediments were deposited by aeolian deposition into grassland vegetation, the removal of grass by fire triggers a period of wind erosion as the underlying soil surface becomes exposed to the elements.

A primary goal of this study was to investigate the postfire recovery process as a burned grassland transitions from a highly erodible condition to a more stable state. Overall, results suggest that wind erosion, as indicated by saltation activity, was at a maximum immediately after the fire when vegetation and threshold were both at a minimum. Saltation activity was shown to steadily decrease each month thereafter as vegetation gradually reclaimed the surface. During the recovery period, the critical threshold of the field increased from less than $10 \mathrm{~m} / \mathrm{s}$ immediately after the fire to above $15 \mathrm{~m} / \mathrm{s}$ in a period of two months, and eventually reached nearly $20 \mathrm{~m} / \mathrm{s}$ three months after the fire. An increase of threshold reduces the probability that winds will exceed threshold to produce bursts of blowing sand and dust.

The results of this experiment demonstrate the importance of measuring threshold as opposed to just measuring saltation activity alone. Saltation activity can be influenced by wind speed, which was observed to decline during the latter part of this study. Threshold, on the other hand, is strictly a function of surface conditions so it is a more precise indicator of the changing erodibility of a surface.

The relationship between vegetation and surface erodibility is best observed by plotting threshold as a function of aboveground biomass. Overall, results suggest that in the early stages of recovery, when the surface had little vegetation, small changes in aboveground biomass produced fairly large changes in threshold and that at later stages, more substantial changes in vegetation were required to produce the same change in threshold.

\section{Acknowledgments}

The author would like to thank James R. Golden for making significant contributions to the design, construction, and maintenance of the sampling systems. I would also like to thank Dr. B.L. Allen and Dr. Richard E. Zartman of Texas Tech University for their careful reviews of this manuscript.

\section{References}

Brown, L., 1979. Grasses, an Identification Guide. Houghton Mifflin, New York, 240 pp.

Cole, D.F., Major, R.L., Wright, L.N., 1974. Effects of light and temperature on germination of sideoats grama. Journal of Range Management 27, 41-44.

Gustavson, T.C., Holliday, V.T., 1999. Eolian sedimentation and soil development on a semiarid to subhumid grassland, Tertiary Ogallala and Quaternary Blackwater Draw formations, Texas and New Mexico high plains. Journal of Sedimentary Research A 69, 622-634.

Holliday, V.T., 1990. Soil and landscape evolution of eolian plains: the southern high plains of Texas and New Mexico. Geomorphology 3, 489-515.

Holliday, V.T., 1991. The geologic record of wind erosion, eolian deposition, and aridity on the southern high plains. Great Plains Research 1, 6-25.

Laprade, K.E., 1957. Dust-storm sediments of Lubbock area, Texas. Bulletin of the American Association of Petroleum Geologists 41, 709-726.

National Agricultural Statistics Service (NASS), 1997. Census of Agriculture. United States Department of Agriculture.

Reeves Jr., C.C., Reeves, J.A., 1996. The Ogallala Aquifer (of the Southern High Plains). In: Geology, vol. 1. Estacado Books, Lubbock, Texas, 360 pp.

Sankey, J.B., Germino, M.J., Glenn, N.F., 2009a. Aeolian sediment transport following wildfire in sagebrush steppe. Journal of Arid Environments 73, 912-919. doi:10.1016/j.jaridenv.2009.03.016.

Sankey, J.B., Germino, M.J., Glenn, N.F., 2009b. Relationships of post-fire aeolian transport to soil and atmospheric conditions. Aeolian Research 1, 75-85. doi:10.1016/j.aeolia.2009.07.002.

Sankey, J.B., Glenn, N.F., Germino, M.J., Gironella, A.I.N., Thackray, G.D., 2010. Relationships of aeolian erosion and deposition with LiDAR-derived landscape surface roughness following wild fire. Geomorphology 119, 135-145. doi:10.1016/ j.geomorph.2010.03.013.

Shantz, H.L., Zon, R., 1924. Natural Vegetation, Atlas of American Agriculture, Part I, Sect. E. Government Printing Office, Washington.

Smart, A.J., Gates, R.N., Richter, H., 2007. After Wildfire: Range Recovery. South Dakota State University Cooperative Extension Service, College of Agriculture \& Biological Sciences in cooperation with the United States Department of Agriculture, Extension Extra 2057, 2 pp. 
Stockton, P., Gillette, D.A., 1990. Field measurements of the sheltering effect of vegetation on erodible land surfaces. Land Degradation \& Rehabilitation 2, 77-85.

Stout, J.E., 2001. Dust and environment in the southern high plains of North America. Journal of Arid Environments 47, 425-441. doi:10.1006/jare.2000.0732.

Stout, J.E., 2004. A method for establishing the critical threshold for aeolian transport in the field. Earth Surface Processes and Landforms 29, 1195-1207.

Stout, J.E., 2010. Diurnal patterns of blowing sand. Earth Surface Processes and Landforms 35, 314-318. doi:10.1002/esp.1919.
Stout, J.E., Lee, J.A., 2003. Indirect evidence of wind erosion trends on the southern high plains of North America. Journal of Arid Environments 55, 43-61. doi:10.1016/S0140-1963(02)00266-5.

Stout, J.E., Zobeck, T.M., 1996. Establishing the threshold condition for soil movement in wind-eroding fields. In: MacFarland, A., Curtit, K., Jacobson, L. (Eds.) Proceedings of International Conference on Air Pollution from Agricultural Operations, February 1996, Kansas City, Missouri. Midwest Plan Service (MWPS C-3), Ames, Iowa, pp. 65-72.

Webb, W.P., 1931. The Great Plains. University of Nebraska Press, Lincoln, 525 pp. 